\title{
Website Satisfaction: Determinants and Consequences on Website Loyalty
}

\author{
Zezia Benhamza Nsairi ${ }^{1} \&$ Manel Khadraoui ${ }^{2}$ \\ ${ }^{1}$ High School of Business, Tunisia \\ ${ }^{2}$ University of Picardie, Jules Verne, Amiens, France \\ Correspondence: Zezia Benhamza Nsairi, High School of Business. Airport road, KM 4. B.P.1081, 3018 Sfax, \\ Tunisia. E-mail: z.benhamzansairi@gmail.com
}

\author{
Received: September 17, 2012 Accepted: October 11, $2012 \quad$ Online Published: August 20, 2013 \\ doi:10.5539/ibr.v6n9p77 URL: http://dx.doi.org/10.5539/ibr.v6n9p77
}

\begin{abstract}
The concept of satisfaction has been a concept extensively studied in the literature and is still of interest to both academics and managers. This study examines the key determinants of satisfaction in an online shopping context and their consequences on loyalty. We have used structural equation modeling method to test a conceptual model relating perceived value-satisfaction-loyalty with the incorporation of variables specific to the online experience (computer anxiety and website environment). We proposed also navigational goal (shopping versus browsing) as a moderator of the relationship between perceived value and satisfaction. The findings reveal that the effect of website environment on perceived value is supported and that some dimensions of perceived value influence online customer satisfaction. Moreover, satisfaction has a positive influence on loyalty while computer anxiety has a negative influence. Furthermore, navigational goal moderates the relationship between perceived value and satisfaction. Managerial implications of these results are discussed.
\end{abstract}

Keywords: satisfaction, website environment, perceived value, loyalty

\section{Introduction}

Due to the development of the internet, a growing body of research has been generated in marketing and ICT (Childers et al., 2001; Lee \& Overby, 2004; Pavlou \& Fygenson, 2006; Dholakia \& Zhao, 2009; Wang et al., 2010; Lien et al., 2011; Luo et al., 2012; Dickinger \& Stangl, 2013; Zhang, 2013). Internet has become an important channel for retailers to effectively reach their target customers or expand into new markets (Hu \& Chuang, 2012). Therefore, it seems essential, for retailers, to understand the consequences induced by Internet particularly on shopping behavior. In fact, the importance of the number of Internet users that shop online was highlighted in a study realized by the CREDOC (2012) (Note 1). According to this study, $69 \%$ of French people have bought by mail-order during these last 12 months (this corresponds to 33.8 millions of persons) and that $96 \%$ of French people who make remote purchasing intend to continue to do so, whether by internet, by mail or by phone. Therefore, our research question will be: how do Internet users evaluate their website navigation's experience and what determines their satisfaction and loyalty?

Satisfaction is, in fact, an important variable to consider especially in an online context as it predicts favorable intentions toward the website (Anderson \& Srinivasan, 2003; Notebart, 2005; Chang \& Wang, 2008; Kim et al., 2009; Lien et al., 2011; Belanche et al., 2012; Dickinger \& Stangl, 2013; Audrain-Pontevia et al., 2013). Consequently, it is interesting to focus on factors that explain online shopper's satisfaction and loyalty. Hence, the objective of this paper will be to test the effect of perceived value of navigation's experience in 3suisses.fr website on customer's satisfaction and loyalty. This paper will start by a presentation of the conceptual background of our research and hypotheses to be tested; after that, we propose our methodology and our results. The last part will deal with discussion of results, implications, limits and future researches.

\section{Conceptual Framework}

\subsection{Theory of Planned Behavior}

A theoretical framework related to the theory of planned behavior (TPB) is used in this study to explain drivers of website loyalty given that TPB has been proven successful in predicting and explaining human behavior and particularly online behavior (Pavlou \& Fygenson, 2006; Liao et al., 2007; Park \& Yang, 2012). 
TPB (Ajzen, 1991) is an extension of the theory of reasoned action (TRA) (Ajzen \& Fishbein, 1980). It tries to predict behavioral intention to engage in a targeted behavior using beliefs, attitude, subjective norms, and perceived behavioral control (Ajzen, 1991). The theory postulates that attitude, as the overall evaluation of the behavior by the individual, is a function of a person's salient beliefs, which represent perceived outcomes or attributes of the behavior. Attitudes and beliefs determine behavior.

In this research, we use the concept of satisfaction as a representation of the attitude since the affective evaluation related to satisfaction's concept is identical to the notion of attitude in the IS-use literature (Melonie, 1990; Kim et al., 2008). We also adopt perceived value as a belief construct following Lee et al. (2007) and Kim et al., (2008). We focus thus on behavioral beliefs, cognitive/affective responses and behavioral intentions and propose a causal relationship between perceived value, satisfaction and behavioral intentions in an online shopping context.

\subsection{Perceived Value}

Two main approaches dominate researches on perceived value. The first one considers it as a judgment comparing perceived benefits to perceived acquisition costs (Zeithaml, 1988; Chen \& Dubinsky, 2003). The second approach treats perceived value as an interaction's situation trait between a subject and an object. It's an "interactive, relative and preferential experience" (Holbrook, 1999, p. 5). In this research, we choose this approach as it considers the whole facets of consumer experience by going beyond the vision to which value is a calculation made by the consumer, characterized by a purely cognitive dimension.

Holbrook (1999) proposes a perceived value's typology based on three dimensions: intrinsic/extrinsic, self-oriented/others-oriented and active/reactive. Eight types of value result from these dimensions: efficiency, excellence, play, aesthetics, status, esteem, ethics and spirituality. These dimensions are not all included in researches validating Holbrook's typology. Hedonic and utilitarian facets are the most studied in the online context (Kim, 2002; Van der Heijden, 2004; Fiore et al., 2005; Yang et al., 2009; Sarkar, 2011; Lien et al., 2011; Hu \& Chuang, 2012). Hedonic value indicates pleasurable benefits such as fantasies, feeling and fun (Holbrook \& Hirschman, 1982). Utilitarian value includes convenience-seeking, variety seeking, searching for quality of merchandise, and reasonable price rate, etc (Sarkar, 2011). In some cases, hedonic value may increase utilitarian value and vice versa (Van der Heijden, 2004). These two value dimensions are presented in table 1.

Table 1. Typology of Internet shopping value (Kim, 2002)

\begin{tabular}{|c|c|c|}
\hline $\begin{array}{l}\text { Holbrook's consumer } \\
\text { value typology }(1999)\end{array}$ & Shopping value & Internet shopping \\
\hline \multirow[t]{2}{*}{ Extrinsic Active } & $\begin{array}{l}\text { Efficiency/ } \\
\text { Convenience }\end{array}$ & $\begin{array}{l}\text { 24-accessibilty at any place: ease of ordering and paying: simple navigational } \\
\text { capabilities; search engines; direct access to a multitude of products/services; } \\
\text { access to specialized goods and services; links to related sites ... }\end{array}$ \\
\hline & $\begin{array}{l}\text { Resources (time, effort and } \\
\text { money) }\end{array}$ & $\begin{array}{l}\text { Internet connection fee, navigation to find a specific item or address; loading } \\
\text { information; transactions; shipping; delivery; computer viruses; broken links; } \\
\text { slow transmission... }\end{array}$ \\
\hline \multirow[t]{2}{*}{ Reactive } & Excellence/Product & Quality, selection, price \\
\hline & $\begin{array}{l}\text { performance } \\
\text { Customer service }\end{array}$ & $\begin{array}{l}\text { Asynchronous contact via e-mail, instructional support; quick product advice; } \\
\text { customization of products/services }\end{array}$ \\
\hline \multirow[t]{2}{*}{ Intrinsic Active } & $\begin{array}{l}\text { Play/Sensory } \\
\text { stimulation/entertainment }\end{array}$ & $\begin{array}{l}\text { Appeal to two senses (sight and sound), web surfing, online puzzles, interactive } \\
\text { games, lottery... }\end{array}$ \\
\hline & Social interaction & Chatting with others who have common interests \\
\hline Reactive & Aesthetics/Ambience & Virtual display, multimedia presentation \\
\hline
\end{tabular}

\subsection{Website Environmental Cues}

A web atmospheric cue is defined as "any web interface component within an individual's perceptual field that stimulates one's senses" (Milliman \& Fugate, 1993, p. 68). It's "the conscious designing of web environments to create positive effects (e.g., positive affect, positive cognitions, etc.) on users in order to increase favourable consumer responses" (Dailey, 2004, p. 796). 
Many typologies of website environmental cues exist. Manganari et al. (2009) propose a typology that classifies website environmental cues into four groups: virtual layout and design, virtual atmospherics, virtual theatrics and virtual social presence. Tarafdar and Zhang (2008) has pointed to a set of website environmental cues such as: content of information, ease of navigation, usability, download speed, customization, security and availability. Ladwein (2001) considers that web interface includes legibility, design (link quality and page organization), animations and website structure. According to Gonzalez (2005), website's layout has four dimensions: method of information classification, visual distinction between website areas, pages clarity and navigational aids. Consumers infer the attractiveness of a product on the basis of information provided by the website and design elements such as navigation easiness and pleasure associated with navigation (Schaupp \& Bélanger, 2005). Therefore, a measure of website environmental cues has to take into account the informational potential of the website and its capacity to facilitate navigation and to create pleasure for Internet users. Eroglu et al. (2001) include these two criteria by proposing a typology of website cues composed of high task-relevant cues and low task-relevant cues. While the first one includes verbal content related to the shopping goals (e.g., descriptions of the merchandise, price, terms of sale, delivery, and return policies), the second one consists of verbal content, which is unrelated to shopping goals such as colors, borders and background patterns, typestyles and fonts, animation, music and sounds, entertainment...

Website characteristics may stimulate or impede navigational experience (Hoffman \& Novak, 1996; Richard, 2005; Tarafdar \& Zhang, 2008; Rose et al., 2012). Therefore, Website characteristics influence website experience and, consequently, the value derived. For example, search engines and shopping cards make it easy for users to interact with websites, while graphics and multimedia make the website interesting and visually appealing (Tarafdar \& Zhang, 2008). According to Rose et al. (2012), characteristics like ease of use, aesthetics, customization (personal tailoring of website appearance and functionality) and connectedness (ability of the website to connect and share knowledge and ideas with others) positively influence Internet users' experiential state. Based on this reasoning, we propose that:

H1: Website environmental cues positively influence perceived value derived from navigational experience

\subsection{Satisfaction}

Satisfaction is a concept that interested many researchers in marketing and continues to be a subject of several researches in webmarketing and ICT (Szymanski \& Hise, 2000; Schaupp \& Bélanger, 2005; Dholakia \& Zhao, 2009; Yoo et al., 2010; Luo et al., 2012; Audrain-Pontevia et al., 2013). Definitions of online and offline satisfaction are quite similar as they both include processes comparing the lived experience to a given standard (disconfirmation paradigm). For Wagner and Rydstrom (2001, p. 277), "if consumers perceive that resources provided by an online retailer meet their needs, satisfaction should result". According to Chang and Wang (2008, p. 11), online satisfaction is "the psychological reaction of the customer with respect to his or her prior experience with comparison between expected and perceived performance".

Researches in marketing and ICT have suggested that a better understanding of satisfaction process results from the analysis of both cognitive and affective facets of satisfaction (Mano \& Oliver, 1993; Arnould \& Price, 1993; Liljander \& Strandvik, 1997; Bhattacherjee 2001; Burns \& Neisner, 2006; Kim et al., 2008; Ltifi \& Gharbi, 2012). According to Oliver (1981, p. 27) satisfaction is "the summary psychological state resulting when the emotion surrounding disconfirmed expectations is coupled with a customer's prior feeling about the customer experience". Others researchers define satisfaction only by its affective facet: "the user's affect with or feeling about prior online product" (Bhattacherjee, 2001), or "a positive, indifferent, or negative feeling following the customer's initial experience with the service" (Anderson \& Srinivasan, 2003). However, as Zhang (2013) stated, there is a lack of agreement on the names, labels, meanings and connotations of affective dimension. He proposed a taxonomy that classifies affective concepts along five dimensions: the residing, the temporal, the particular/general stimulus, the object/behavior stimulus, and the process/outcome dimensions, and suggested that satisfaction with a website is an outcome-based affective evaluation toward behaviors on a particular object.

Customer satisfaction pertains to a particular focus: product/service or purchase/consumption experience (Giese $\&$ Cote, 2000). Some researches focused on satisfaction with product as an evaluation of the product performance (Day, 1984; Westbrook \& Oliver, 1991; Mano \& Oliver, 1993). Other studies (Szymanski \& Hise, 2001; Liu et al., 2008; Lien et al., 2011; Rose et al., 2012) examined satisfaction with purchasing or shopping experience and consider all the experience. This experience is not solely derived by the product purchased, but includes particular events of a service transaction (e.g., specific employee actions). Our research is in line with these studies as we focus on the assessment given by Internet users to their overall online shopping experience. According to Szymanski and Hise (2000), product information, website design and financial security contribute 
to the formation of online satisfaction. Mckinney et al. (2002) distinguished two sources of satisfaction: the informational content quality and the performance of the website to provide necessary information. Liu et al. (2008) examined the following determinants of online customer satisfaction: convenience, trust, website design, information, assurance, merchandise variety, perceived usefulness, perceived ease of use, reliability, entertainment, speed, response time and transaction capability. More recently, Luo et al. (2012) argued that levels of product uncertainty and high retailer visibility affect online satisfaction.

Experiential value may be one factor that contributes to online satisfaction. Oliver (1999) stated that if value such as efficiency, excellence, status, entertainment and aesthetics are reached, satisfaction should occur. Like some researchers (Yang \& Peterson, 2004; Chang \& Wang, 2008), we consider that in online context, perceived value can be one of the determinants of satisfaction. In fact, in an online shopping context, Lien et al. (2011) have proven that perceived value influence satisfaction. Yoo et al. (2010) studied utilitarian and hedonic perceived value of e-shopping and showed their positive relationships with satisfaction. The same result was supported by Mouakket and Al-hawari (2012) in their study of the antecedents of e-loyalty intention in an online reservation environment. We hypothesize that:

H2: Perceived value of navigation experience positively influences satisfaction.

\subsection{Loyalty}

Loyalty has been studied through three main approaches. The first one is behavioral and conceives loyalty in terms of repeat purchasing. The second one is attitudinal and surpasses the shortcomings of the first approach. Indeed, the mere observation of repetitive behavior does not necessarily reflect a deliberate choice and a dedicated membership. Attitudinal approach considers loyalty as a favorable attitude toward the object of loyalty (Anderson \& Srinivasan, 2003; Shankar 2003; Frisou, 2005). The behavioral and attitudinal approaches are combined to form a multifaceted conception of loyalty. Dick and Basu (1994) proposed a model of loyalty that combines two axes: relative attitude and behavior. Accordingly, loyalty occurs in the presence of strong relative attitude and high repurchasing rate. The following table below presents definitions of loyalty according to the three approaches.

Table 2. Definitions of loyalty

\begin{tabular}{ll}
\hline Approach & Definition \\
\hline Behavioral loyalty & "Customers' repetitive purchasing with an organization" (Shankar et al., 2000, p.1) \\
"Repurchase models or behavioral frequency" (Evanschitzky \& Wunderlich, 2006, p.337) \\
"A high level of commitment to the firm" (Shankar et al., 2003, p.154) \\
" The intention of a consumer to repurchase products/services through a particular e-service \\
vendor" (Luaran \& Lin, 2003, p.157) \\
"A hypothetical construct. As the attitude, it is supposed to determine the long-term strength \\
and direction of consumer buying behavior toward a brand" (Frisou, 2005, p.106) \\
"The customer's favorable attitude toward an electronic business resulting in repeat buying \\
behavior" (Anderson \& Srinivasan, 2003, p.125) \\
"The biased behavioral re-patronage intention, expressed \\
over time, of a customer with respect to an online store out of a set of online stores, which is a \\
function of psychological decision-making and evaluative processes resulting in store \\
commitment" (Koo, 2006, p. 121) \\
"The consumer's desire to frequent a particular service provider, resulting from high customer \\
satisfaction, high emotional commitment and sustained repeat purchase behavior" (Salegna \& \\
Goodwin, 2005, p.54)
\end{tabular}

This study will focus on attitudinal loyalty through three facets: revisiting intention, repurchase intention and word-of-mouth intention. Revisiting intention is an important dimension of website navigation experience since those who visit a website more frequently are more likely to buy from it (Moe, 2003). Repurchase intention is also important as it's very close to buying behavior despite the fact that there are other constraints for behavior to 
occur. Positive word-of mouth intention is a free means of communication from which the company can benefit. This phenomenon is growing with the rapidity of information transmission on the web and the importance of audience.

The study of online loyalty antecedents constitutes an interesting goal for retailers since the acquisition costs of new customers are very high (Reichheld \& Schefter 2000). Satisfaction may be one of these antecedents (Anderson \& Srinivasan, 2003; Notebart, 2005; Chang \& Wang, 2008; Dholakia \& Zhao, 2009; Wang et al., 2010). The relationship between satisfaction and loyalty was supported in the works of Lai et al. (2009), Trasorras et al. (2009) and Helm et al. (2010). Dickinger and Stangl (2013) have also proven that website satisfaction positively influences website loyalty. For Lien et al. (2011), satisfaction determines behavioral intentions. Belanche et al. (2012) showed that website satisfaction positively influences intention to use in the future. In fact, if Internet user is satisfied with the website navigation experience, he may develop favorable intentions toward this website. We can, thus, suggest the following hypothesis:

H3: Satisfaction with navigation experience positively influences website loyalty.

\subsection{Computer Anxiety}

Computer anxiety is a concept that has for long time interested researchers. It has grown with the proliferation of computer use and the diversity of consumers' perceptions, feelings and behavior toward this machine. Martin (1998, p. 16) defines computer anxiety as: "Uneasiness that is conscious to a person while working with a computer". It is also "negative emotions and cognitions evoked in actual or imaginary interaction with a computer-based technology" (Bozionelos, 2001, p. 213). It is, therefore, a specific trait related to computer situation use. Korukonda (2007, p. 1921) propose that "computer anxiety, as defined and operationalized in the human-computer studies literature, has been synonymous to negative thoughts and attitudes about the use of computers". Consequently, persons with high level of computer anxiety are more likely to develop stress, tensions and embarrassment in this situation. So, computer anxiety causes discomfort and may inhibit positive attitude of computer users having this specific situation trait. Compeau et al. (1999) found that computer anxiety is negatively linked to its use. Meuter et al. (2003) treated a broader concept which is technology anxiety and showed that this type of anxiety has a strong negative effect on self-service technology adoption. Lee et al. (2010) have also shown that technology anxiety negatively influences intention to use. Mouakket and Al-hawari (2012) called for the extension of the theoretical framework on customer loyalty by integrating computer anxiety as additional variable. Therefore, we propose the following hypothesis:

H4: Computer anxiety negatively influences website loyalty.

\subsection{Buying and Browsing Behaviors on the Web}

In 1983, Bloch and Richins noted the existence of an in-store behavior, named browsing, which is outside the purchase context, motivated mainly by recreational purposes; Lombart (2001) has extended the study of this behavior by focusing on its determinants and consequences for retailers. In web studies, browsing, which is called e-surfing (Lombart \& Jeandrain, 2003, p. 14) is considered as "visiting virtual stores for recreational motives without a current intent to buy".

Helme-Guizon (2001, p. 31) distinguishes between goal-directed behavior which aims to search for a particular product and/or information related, and experiential behavior defined as "strolling within websites or from website to another by a person to search for pleasure, emotions and sensations". Therefore, consumers shop for both hedonic and utilitarian purposes. In line with marketing studies that distinguish between these two goals, researchers in online context make the same distinction. Indeed, the web serves both hedonic and utilitarian purposes and the nature of the websites that people surf determines which belief takes precedence (Van der Heijden, 2004). Utilitarian purpose implies that there is an objective external to the interaction between the user and the system; while hedonic purpose does not aim to facilitate such objective, it is the fun or pleasure derived from using a technology (Venkatesh et al., 2012; Van der Heijden, 2004). For some researchers, when consumers begin to use a particular technology, the level of hedonic motivation is high, this level will decrease over time and consumers will use the technology for more pragmatic purposes (Venkatesh et al., 2012). Therefore, browsing may concern more the new websites or those with high level of sensory or cognitive stimulation. Overall, hedonic and utilitarian motivations both aim to incorporate the functional and pleasurable dimensions into users' experiences and keep users emotionally, cognitively, and physically involved in the interaction (O'Brien, 2010).

Recent studies have recognized the existence of two types of web users having these two shopping orientations and differing in terms of perception and effective behavior (Wang et al., 2010; Broekhuizen \& Huizingh, 2009; O'Brien, 2010). Therefore, like Audrain-Pontevia et al. (2013), we suppose that the relationship between 
perceived value and satisfaction depends on the type of online purchase (goal-directed vs. exploratory). Because of their initial motivation, browsers would be more satisfied with hedonic component of navigation's experience while buyers would be more satisfied with utilitarian aspects of navigational experience. Therefore:

H5: Navigational goal (buying versus browsing) moderates the relationship between perceived value of navigational experience and satisfaction.

The conceptual model related to this research is therefore, represented in figure 1 .

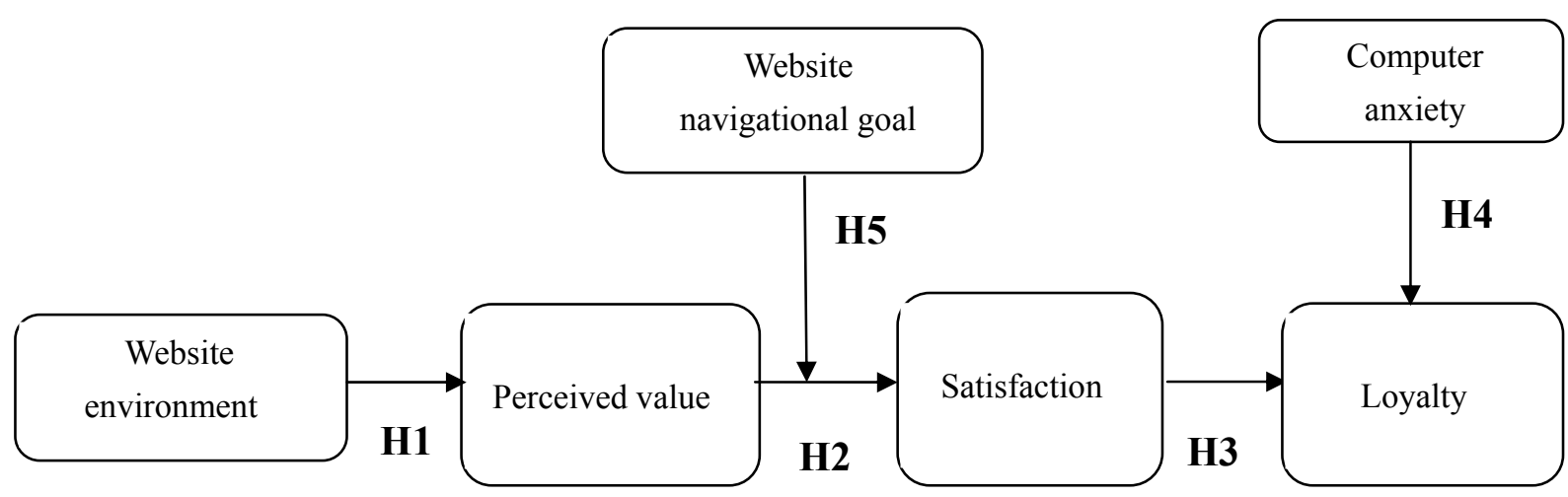

Figure 1. Conceptual model

\section{Methodology and Results}

\subsection{Data Collection}

Data collection was undertaken online. The site chosen is 3suisses.fr; this is a site of clothing and home ware by mail-order. This is one of the leading sites that buy online in France. In fact, according to statistics of the federation of e-commerce and mail-order corresponding to April, May and June 2009, 3suisses is the third site of mail-order online and surpasses its main competitor La Redoute. This site was chosen because it offers the possibility to make purchases, to search for new products and to navigate just for pleasure. Internet users were contacted by email and invited to participate to the study. A pilot study was carried on followed by an invitation to discuss difficulties of the experimentation and/or questionnaire. In this study, participants were free to choose the objective of the visit. However, many of them declare that the objective changed along the visit and they were not able to answer the filter question. Therefore, we have decided to conceive a scenario asking participants to pursue only one objective: utilitarian or exploratory. The manipulation of the objective of the visit is an artificial method of data collection but is very used in experimental studies (Bonitz et al., 2010; Khare, 2011; Shu \& Cheng, 2012) and it has also the merit to provide comparable number of participants according to the objective of the visit. 120 usable questionnaires were returned by email. Characteristics of the sample can be found in Annex 1. The method of data analysis adopted is structural equation modeling. Data was analyzed with SPSS and AMOS programs.

\subsection{Presentation and Analyses of Measurement Scales}

All the items use a Likert scale anchored at 5 points. The list of scales used is provided in Annex 2. For the moderator variable "website navigational goal", which is composed of buying behavior or exploratory behavior, we have used Beatty and Ferrel's (1998) measurement scale. The means of the three items is calculated for each individual. A value of 3 or less informs us that the objective pursued is utilitarian. A value surpassing 3 allows us to classify the individual objective as exploratory. We have proceeded to exploratory and confirmatory analysis of measurement scales. Results are summarized in the following table.

All the scales present good Cronbach's alpha with values superior to 0.7 except for excellence. The cumulative percentage of information retrieved is also very satisfying. We note that Joreskog Rho surpasses 0.7 except for "excellence" with a very close value. Discriminant validity is also confirmed according to Fornell and Larker (1981). Data doesn't suggest a second-order structure of perceived value because correlations between 
Table 3. Results of exploratory and confirmatory factor analysis

\begin{tabular}{|c|c|c|c|c|c|c|}
\hline Concept & Dimensions & $\begin{array}{c}\text { Number of retained } \\
\text { items }\end{array}$ & Alpha & $\begin{array}{c}\text { Cumulative } \% \text { of information } \\
\text { retrieved }\end{array}$ & AVE & $\begin{array}{c}\text { Joreskog } \\
\text { Rhô }\end{array}$ \\
\hline \multirow{5}{*}{ Perceived value (Note 2 ) } & Visual appeal & 3 & .903 & 12.058 & .758 & .904 \\
\hline & Entertainment & 3 & .875 & 31.584 & .711 & .880 \\
\hline & Escapism & 3 & .941 & 57.072 & .849 & .944 \\
\hline & Excellence & 2 & .656 & 63.452 & .497 & .663 \\
\hline & Efficiency & 3 & .915 & 74.626 & .780 & .914 \\
\hline & Quality/price ratio & 3 & .856 & 83.385 & .680 & .864 \\
\hline Satisfaction & Unidimensional & 3 & .825 & 74.557 & .627 & .833 \\
\hline \multirow{4}{*}{$\begin{array}{l}\text { Website environment } \\
\qquad \text { (Note 3) }\end{array}$} & Navigability & 3 & .764 & 9.452 & .530 & .767 \\
\hline & Structure & 3 & .914 & 23.585 & .782 & .914 \\
\hline & Entertainment & 3 & .864 & 39.829 & .696 & .971 \\
\hline & $\begin{array}{l}\text { Informational } \\
\text { character }\end{array}$ & 5 & .805 & 71.627 & .461 & .808 \\
\hline Loyalty & Unidimensional & 3 & .872 & 80.058 & .703 & .876 \\
\hline Computer anxiety & Unidimensional & 4 & .846 & 69.524 & .607 & .859 \\
\hline
\end{tabular}

constructs of first-order and second-order are weak, alike for the correlations between constructs of first-order. However, for website environment, the correlations are comprised between 0.5 and 0.53 . This second-order structure has the advantage to simplify the model.

\subsection{Analysis and Discussion of Results}

Fit indexes of the structural model are presented in table 4. They are acceptable and in accordance with the commonly recommended thresholds.

Table 4. Overall model fit

\begin{tabular}{lllllll}
\hline $\mathrm{Chi}^{2}$ & $\mathrm{df}$ & $\mathrm{p}$ & Normed $\mathrm{Chi}^{2}$ & GFI & CFI & RMSEA \\
\hline 1022.955 & 719 & 0.000 & 1.455 & 0.892 & 0.902 & 0.060 \\
\hline
\end{tabular}

Results regarding test of hypotheses are summarized in the following table.

These results show that website environment positively influences all the dimensions of perceived value except for the quality/price ratio. Visual appeal is the value dimension the most influenced by website environment, the second one is entertainment. These two dimensions describe the aesthetic value according to Holbrook's (1999) typology. Given that the environment "stimulates one's senses" (Milliman \& Fugate, 1993, p. 68), it seems that the website environment strengths the aesthetic aspect of the latter (Wang et al., 2010). For play value (escapism), an attractive website design and an easy navigability facilitate the sensation to be away from everyday problems. The conception of the website environment retained in this study includes also elements that make the navigation easier for the achievement of an objective. It was shown that, when judging the excellence of the service, the Internet user integrates all the elements of the offer, even the website environment. For the economic value, the perception of the ratio quality/price is still out of the influence of the website environment. However, the latter has a positive effect on the perception of website efficiency (easiness, facility, convenience). This result is in accordance with conclusions of Ladwein (2001) related to the impact of functional elements of the website on the comfort and easiness of use.

We have supposed that perceived value, with its utilitarian and hedonic dimensions, is an antecedent of satisfaction. Our results sustain this relationship. However, we have found that visual appeal is the most 
Table 5. Coefficients of the structural model

\begin{tabular}{llll}
\hline Relations tested & $\begin{array}{l}\text { Unstandardized } \\
\text { coefficients }\end{array}$ & $\begin{array}{l}\text { Standardized } \\
\text { coefficients }\end{array}$ & CR \\
\hline Website environment - visual appeal & 1.416 & .718 & 4.881 \\
Website environment - entertainment & 1.228 & .563 & 3.320 \\
Website environment - escapism & 0.960 & .355 & 3.335 \\
Website environment - excellence & 0.892 & .447 & 1.787 \\
Website environment - efficiency & 0.394 & .197 & 1.439 \\
Website environment - quality/price ratio & 0.371 & .165 & 6.300 \\
Visual appeal - satisfaction & 0.446 & .517 & .351 \\
Entertainment - satisfaction & 0.020 & .025 & 1.927 \\
Escapism - satisfaction & 0.078 & .124 & 3.103 \\
Excellence - satisfaction & 0.270 & .317 & .180 \\
Efficiency - satisfaction & 0.153 & .270 & 3.815 \\
Quality/price ratio - satisfaction & 0.204 & .933 & 3.699 \\
Satisfaction - loyalty & 1.028 & -.108 & 10.961 \\
Computer anxiety - loyalty & -0.089 & & -1.692 \\
\hline
\end{tabular}

important dimension in the determination of satisfaction. This result confirms the importance of hedonic value in the online navigational experience (Childres et al., 2001; Lee et al., 2009). Extrinsic values (excellence and economic) play also a critical role in the formation of online satisfaction. In this vein, Lemmink et al. (1998) have found that extrinsic (utilitarian), intrinsic (emotional) and systematic (quality/price ratio) value of a service determine consumer satisfaction. The relationship between satisfaction and loyalty was also confirmed in this study. This result corresponds to those found by many researchers (Lin \& Wang, 2006; Kim et al., 2009; Berné et al., 2001; Reibstein, 2002; Audrain-Pontevia et al., 2013).

Computer anxiety negatively influences loyalty. This variable was presented as a barrier for the adoption of computers to realize tasks requiring use of this machine. Its role in the determination of loyalty is not as important as satisfaction but it's useful to consider in explaining favorable intentions toward the website. Website navigational goal moderates the relationship between perceived value and satisfaction given that the links visual appeal-satisfaction and entertainment-satisfaction are stronger with exploratory visitors than with those pursuing a utilitarian goal. Therefore, the valorization of aesthetic experience is more important in the determination of satisfaction for exploratory visitors than for shoppers with utilitarian goals. This result is confirmed by Wang et al. (2010). Accordingly, it is important to consider shopping orientation of Internet users because pursuing a utilitarian or a hedonic goal induces the Internet user to evaluate differently the aesthetic dimension of the website.

To test the moderator role, we have used multi-group analyses. The test of difference of chi ${ }^{2}$ between nested models shows that there are only two links that are significantly different between the two groups which are visual appeal-satisfaction and entertainment-satisfaction. The comparative analysis between the groups shows that the link between visual appeal and satisfaction is stronger for exploratory goal than for utilitarian ones. On the other hand, the relationship between entertainment and satisfaction is positive and significant for exploratory goal and non significant for utilitarian goal proving that entertainment is not important in case of purchase because visitors are caring about efficiency of the visit rather than spending good time.

\section{Conclusion}

This study showed that the website environment influences perceived value which determines satisfaction. Loyalty is predicted by satisfaction and computer anxiety. The website navigational goal moderates the link between hedonic dimension of perceived value and satisfaction. These findings allow us to make important

conclusions and practical implications for managers. In fact, our study shows that website environment has the biggest influence on visual appeal. The latter is the most important in the determination of satisfaction. 
Table 6. Test of the moderator effect of website navigational goal

\begin{tabular}{llll}
\hline & $\Delta \mathrm{chi}^{2}(\mathrm{df} ; \mathrm{p})$ & \multicolumn{2}{l}{ Unstandardized coefficients of regression } \\
& & Utilitarian goal & Exploratory goal \\
\hline Visual appeal-satisfaction & $3.680(1 ; 0.055)$ & $0.344(0.000)$ & $0.603(0.000)$ \\
Entertainment-satisfaction & $6.437(1 ; 0.010)$ & $-1.20(0.142)$ & $0.216(0.039)$ \\
\hline
\end{tabular}

Consequently, managers should pay attention to the aesthetic aspect of website design. Therefore, important tactics that should be employed are the inclusion of hedonic content, animated images, colors, sounds, etc to encourage "prolonged use" (Van der Heijden, 2004). Aside from aesthetic beauty, it is recommended to consider dreams and imaginations of Internet users to create a captivating theme setting. This may be allowed by a value co-creation where an inference is realized between customers' tests and their preferences for products and website design (choice of colors, modern or classical aspect, nostalgia...). Such practices represent a means to reinforce the personalization of relationships and to keep existing customers and attract new ones (Wang et al., 2010).

This study shows that achieving customer satisfaction through enhancing some dimensions of customer value is a way to earn online customer loyalty. This helps managers to understand drivers of e-loyalty if they aim to develop and maintain loyal customers in e-space. Managers should make distinction between buyers and browsers and work on websites characteristics which enhance online shopping value for both consumers type. Indeed, it's not necessary to afford website pleasurable experiences if customers are mainly buyers. The latest are more satisfied by practical experiences that reduce their product uncertainty and enhances retailer visibility (Luo et al., 2012).

Computer anxiety represents a consumer characteristic and the role of managers is still limited to influence this variable. However, "the degree of computer anxiety may change easily" (Panagiotakopoulos \& Koustourakis, 2001, p. 36). Notably, the experience and computer knowledge can reduce this anxiety. Hence, it's important to consider the characteristics of customers and to offer a content that is adapted to their level of computer skills.

This research has some limits. First, perceived value was considered only through its individual dimension. Social interaction was not taken into account because measurement scale used does not encompass all the axes in the typology of value (Holbrook, 1999). Then, the use of second-order structure of environment has certainly facilitated the analysis but does not give information about the relative importance of dimensions of website environment. For future research, we propose to take into account these limits and to integrate other variables in the determination of website loyalty such as trust which is a rich concept likely to give more explanation to loyalty variance. Other variables may have a moderator role, notably, familiarity with Internet in general and particularly with the website.

\section{References}

Ajzen, I. (1991). The theory of planned behaviour. Organizational Behaviour and Human Decision Processes. 50(2), 179-211. http://dx.doi.org/10.1016/0749-5978(91)90020-T

Ajzen, I., \& Fishbein, M. (1980). Understanding Attitudes and Predicting Social Behavior. Englewood Cliffs, NJ: Prentice-Hall.

Anderson, E., \& Srinivasan, S. S. (2003). E-satisfaction and e-loyalty: a contingency framework. Psychology and Marketing, 20(2), 123-138. http://dx.doi.org/10.1002/mar.10063

Arnould, E. J., \& Price, L. L. (1993). River magic: extraordinary experience and the extended service encounter. Journal of Consumer Research, 1(20), 24-45. http://dx.doi.org/10.1086/209331

Audrain-Pontevia, A. F., N'goala, G., \& Poncin, I. (2013). A good deal online: The Impacts of acquisition and transaction value on E-satisfaction and E-loyalty. Journal of Retailing and Consumer Services, 20(3), 1-8. http://dx.doi.org/10.1016/j.jretconser.2013.04.002

Beatty, S. E., \& Ferrell, M. E. (1998). Impulse buying: modeling its precursors. Journal of Retailing, 74(2), 169-191. http://dx.doi.org/10.1016/S0022-4359(99)80092-X

Berné, C., Mùgica, J. M., \& Yagüe, M. J. (2001). The effect of variety-seeking on customer retention in services. Journal of Retailing and Consumer Services, 8(6), 335-345.

Belanche, D., Casalo, L. V., \& Guinaliu, M. (2012). Website usability, consumer satisfaction and the 
intention to use a website: The moderating effect of perceived risk. Journal of Retailing and Consumer Services, 19, 124-132.

Bhattacherjee, A. (2001). Understanding information systems continuance: An expectation-confirmation model. MIS Quarterly, 25(3), 351-370. http://dx.doi.org/10.2307/3250921

Bloch, P. H., \& Richins, M. L. (1983). Shopping without purchase: an investigation of consumer browsing behavior. Advances in Consumer Research, 10, 389-393.

Bonitz, V. S., Larson, L. M., \& Armstrong, P. I. (2010). Interests, self-efficacy, and choice goals: An experimental manipulation. Journal of Vocational Behavior, 76(2), 223-233. http://dx.doi.org/10.1016/j.jvb.2009.09.003

Bozionelos, N. (2001). Computer anxiety: relationship with computer experience and prevalence. Computers in Human Behavior, 17, 213-224.

Broekhuizen, T., \& Huizingh, E. K. R. E. (2009). Online purchase determinants: is their effect moderated by direct experience? Management Research News, 32(5), 440-450. http://dx.doi.org/10.1108/01409170910952949

Burns, D. J., \& Neisner, L. (2006). Customer satisfaction in a retail setting, the contribution of emotion. International Journal of Retailing and Distribution Management, 34(1), 49-66.

Chang, H. H., \& Wang, H. W. (2008). The relationships among e-service quality, value, satisfaction and loyalty in online shopping. European Advances in Consumer Research, 8, 10-15.

Chen, Z., \& Dubinsky, A. J. (2003). A conceptual model of perceived customer value in e-commerce: a preliminary investigation. Psychology \& Marketing, 20(4), 323. http://dx.doi.org/10.1002/mar.10076

Childers, T. L., Carr, C. L., \& Carson, P. S. (2001). Hedonic and utilitarian motivations for online retail shopping behavior. Journal of Retailing, 77, 511-535. http://dx.doi.org/10.1016/S0022-4359(01)00056-2

Churchill, G., \& Surprenant, C. (1982). An investigation into the determinants of customer satisfaction. Journal of Marketing Research, 19, November, 491-504. http://dx.doi.org/10.2307/3151722

Dailey, L. (2004). Navigational web atmospherics: Explaining the influence of restrictive navigation cues. Journal of Business Research, 57, 795-803. http://dx.doi.org/10.1016/S0148-2963(02)00364-8

Dholakia, R. R., \& Zhao, M. (2009). Retail web site interactivity: How does it influence customer satisfaction and behavioral intentions? International Journal of Retail \& Distribution Management, 37(10), 821-838. http://dx.doi.org/10.1108/09590550910988011

Dick, A. S., \& Basu, K. (1994). Customer loyalty: toward an integrated conceptual framework. Journal of the Academy of Marketing Science, 22(2), 99-113. http://dx.doi.org/10.1177/0092070394222001

Dickinger, A., \& Stangl, B. (2013). Website performance and behavioral consequences: A formative measurement approach. Journal of Business Research, 66, 771-777.

Eroglu, S. A., Machleit, K. A., \& Davis, L. M. (2001). Atmospheric qualities of online retailing: a conceptual model and implications. Journal of Business Research, 50, 177-184. http://dx.doi.org/10.1016/S0148-2963(99)00087-9

Eroglu, S. A., Machleit, K. A., \& Davis, L. M. (2003). Empirical testing of a model of online store atmospherics and shopper responses. Psychology \& Marketing, 20(2), 139-150. http://dx.doi.org/10.1002/mar.10064

Evanschitzky, H., Iyer, G. R., Hesse, J., \& Ahlert, D. (2004). E-satisfaction: a re-examination. Journal of Retailing, 80, 239-247.

Fiore, A. M., Kim, J., \& Lee, H. (2005). Effect of image interactivity technology on consumer responses toward the online retailer. Journal of Interactive Marketing, 19(3), 38-53. http://dx.doi.org/10.1002/dir.20042

Fornell, C., \& Larker, D. E. (1981). Structural equation models with unobservable variables and measurement error: algebra and statistics. Journal of Marketing Research, 18, 382-388. http://dx.doi.org/10.2307/3150980

Frisou, J. (2005). Une approche tendancielle du comportement de fidélité : du concept à sa mesure. Recherche et Applications en Marketing, 20(2), 105-125. http://dx.doi.org/10.1177/076737010502000205

Giese, J. L., \& Cote, J. A. (2000). Defining customer satisfaction. Academy of Marketing Science Review, 1, $1-34$.

Gonzalez, C. (2005). Satisfaction du consommateur suite à la visite du catalogue électronique: impact de la 
lisibilité perçue et de la stimulation perçue. Revue Française du Marketing, 205, 91-110.

Gremler, D. (1995). The effect of satisfaction, switching costs, and interpersonal bonds on service loyalty. Rapport de Ph.D., Arizona State University.

Heinssen, R. K., Glass, C. R., \& Knight, L. A. (1987). Assessing computer anxiety: Development and validation of the Computer Anxiety Rating Scale. Computers in Human Behavior, 3, 49-59. http://dx.doi.org/10.1016/0747-5632(87)90010-0

Helme-Guizon, A. (2001). Le comportement du consommateur sur un site marchand est-il fondamentalement différent de son comportement en magasin? Proposition d'un cadre d'appréhension de ses spécificités. Recherche et Applications en Marketing, 16(3), 25-38. http://dx.doi.org/10.1177/076737010101600303

Hu, F. L., \& Chuang, C. C. (2012). A study of the relationship between the value perception and loyalty intention toward an e-retailer website. Journal of Internet Banking and Commerce, 17(1), 1-18. Retrieved from http://www.arraydev.com/commerce/jibc/

Hoffman D. L., Novak T. P. (1996), Marketing in hypermedia computer-mediated environments: conceptual foundations. Journal of Marketing, 60(3), 50-68. http://dx.doi.org/10.2307/1251841.

Holbrook, M. B. (1999). Consumer value: a framework for analysis and research. London: Routledge. http://dx.doi.org/10.4324/9780203010679

Khare, A., Labrecque, L. I., \& Asare, A. K. (2011). The assimilative and contrastive effects of word-of-mouth volume: An experimental examination of online consumer rating. Journal of Retailing, 87(1), 1111-1126. http://dx.doi.org/10.1016/j.jretai.2011.01.005

Kim, C., Zhao, W., \& Young, K. H. (2008). An empirical study on the integrated framework of e-CRM in online shopping: evaluating the relationships among perceived value, satisfaction, and trust based on customers' perspectives. Journal of Electronic Commerce in Organizations, 6(3), 1-19.

Kim, J., Jin, B., \& Swinney, J. L. (2009). The role of e-tail quality, e-satisfaction and e-trust in online loyalty development process. Journal of Retailing \& Consumer Services, 16(4), 239-247. http://dx.doi.org/10.1016/j.jretconser.2008.11.019

Kim, Y. K. (2002). Consumer value: An application to mall and Internet shopping. International Journal of Retail \& Distribution Management, 30(11/12), 595-602. http://dx.doi.org/10.1108/09590550210453075

Korukonda, A. R. (2007). Differences that do matter: A dialectic analysis of individual characteristics and personality dimensions contributing to computer anxiety. Computers in Human Behavior, 23, 1921-1942. http://dx.doi.org/10.1016/j.chb.2006.02.003

Ladwein, R. (2001). L'impact de la conception des sites de e-commerce sur le confort d'utilisation: une

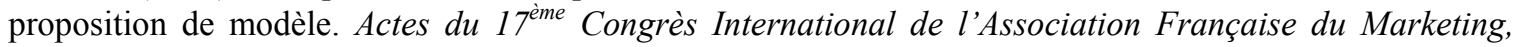
Deauville.

Lai, F., Griffin, M., \& Babin, B. J. (2009). How quality, value, image, and satisfaction create loyalty at a Chinese telecom. Journal of Business Research, 62(10), 980-986. http://dx.doi.org/10.1016/j.jbusres.2008.10.015

Lee, E. J., \& Overby, J. W. (2004). Creating value for online shoppers: implications for satisfaction and loyalty. Journal of Consumer Satisfaction, Dissatisfaction and Complaining Behavior, 17, 54-67.

Lee, H. J., Cho, H. J., Xu, W., \& Fairhurst, A. (2010). The influence of consumer traits and demographics on intention to use retail self-service checkouts. Marketing Intelligence \& Planning, 28(1), 46-58. http://dx.doi.org/ 10.1108/02634501011014606

Lee, M. Y., Kim, Y. K., \& Fairhurst, A. (2009). Shopping value in online auctions: Their antecedents and outcomes. Journal of Retailing and Consumer Services, 16, 75-82.

Lee, Y. K., Tseng, S. P., Liu, F. J., \& Liu, S. C. (2007). Antecedents of learner satisfaction toward e-learning. Journal of American Academy of Business, 11(2), 16-168.

Liao, C., Chen, J. L., \& Yen, D. C. (2007). Theory of planning behavior (TPB) and customer satisfaction in the continued use of e-service: An integrated model. Computers in Human Behavior, 23, 2804-2822. http://dx.doi.org/10.1016/j.chb.2006.05.006

Lien, C. H., Wen, M. J., \& Wu, C. C. (2011). Investigating the relationships among e-service quality, perceived value, satisfaction, and behavioral intentions in Taiwanese online shopping. Asia Pacific Management Review, 16(3), 211-223. 
Liljander, V., \& Strandvik, T. (1997). Emotions in service satisfaction. International Journal of Service Industry Management, 8(2), 149-171. http://dx.doi.org/ 10.1108/09564239710166272

Lin, H. H., \& Wang, Y. S. (2006). An examination of the determinants of customer loyalty in mobile commerce contexts. Information \& Management, 43(4), 271-282. http://dx.doi.org/10.1016/j.im.2005.08.001

Liu, X., He, M., Gao, F., \& Xie, P. (2008). An empirical study of online shopping customer satisfaction in China: a holistic perspective. International Journal of Retail \& Distribution Management, 36(11), 919-940. http://dx.doi.org/10.1108/09590550810911683

Lombart, C. (2001). Fréquentation des magasins et non-achat: le cas du butinage. Actes $d u 17^{\text {ème }}$ Congrès International de l'Association Française du Marketing, Deauville.

Lombart, C., \& Jeandrain, A. C. (2003). Contrasting browsing in retail stores and e-surfing: Antecedents and consequences. The $30^{\text {th }}$ International Research Seminar in Marketing, Lalonde les Maures.

Ltifi, M., \& Gharbi, J. (2012). E-satisfaction and e-loyalty of consumers shopping online. Journal of Internet Banking and Commerce, 17(1), 1-20. Retrieved from http://www.arraydev.com/commerce/jibc/

Luo, J., Ba, S., \& Zhang, H. (2012). The effectiveness of online shopping characteristics and well-designed websites on satisfaction. MIS Quarterly, 36(4), 1131-1144.

Manganari, E. E., Siomkos, G. J., \& Vrechopoulos, A. P. (2009). Store atmosphere in web retailing. European Journal of Marketing, 43(9/10), 1140-1153. http://dx.doi.org/ 10.1108/03090560910976401

Mano, H., \& Oliver, R. L. (1993). Assessing the dimensionality of structure of the consumption experience: evaluation, feeling and satisfaction. Journal of Consumer Research, 20(3), 451-466. http://dx.doi.org/ $10.1086 / 209361$

Martin, B. L. (1998). Computer anxiety levels of Virginia cooperative extension field personnel, Thèse de doctorat. Virginia Polytechnic Institute and State University.

Mathwick, C. (2002). Understanding the online consumer: A typology of online relational norms and behavior. Journal of Interactive Marketing, 16(1), 40-55. http://dx.doi.org/ 10.1002/dir.10003

Mathwick, C., Malhotra, N., \& Rigdon, E. (2001). Experiential value: conceptualization, measurement and application in the catalog and Internet shopping environment. Journal of Retailing, 77(1), 39-56. http://dx.doi.org/10.1016/S0022-4359(00)00045-2

Melone, N. P. (1990). A theoretical assessment of the user-satisfaction construct in information systems research. Management Science, 36(1), 76-81. http://dx.doi.org/10.1287/mnsc.36.1.76

McKinney, V., Yoon, K., \& Zahedi, F. M. (2002). The measurement of web-customer satisfaction: An expectation and disconformation approach. Information Systems Research, 13(3), 296-315. http://dx.doi.org/10.1287/isre.13.3.296.76

Miller, M. D., \& Rainer, R. K. (1995). Assessing and improving the dimensionality of the computer anxiety rating scale. Educational and Psychological Measurement, 55, 662-657.

Milliman, R. E., \& Fugate, D. L. (1993). Atmospherics as an emerging influence in the design of exchange environments. Journal of Marketing Management, 3, 66-74.

Mouakket, S., \& Al-hawari, M. A. (2012). Examining the antecedents of e-loyalty intention in an online reservation environment. Journal of High Technology Management Research, 23, 46-57. http://dx.doi.org/10.1016/j.hitech.2012.03.005

Moe, W. W. (2003). Buying, searching, or browsing: differentiating between online shoppers using in-store navigational clickstream. Journal of Consumer Psychology, 13(1/2), 29-39.

Notebart, J. F. (2005). L'influence de la création d'un lien social via Internet sur la satisfaction, la confiance et les intentions comportementales. Actes du 2lème Congrès de l'Association Française du Marketing, Nancy.

O'Brien, H. L. (2010). The influence of hedonic and utilitarian motivations on user engagement: The case of online shopping experiences. Interacting with Computers: Special Issue on User Experience, 22(4), 344-352. http://dx.doi.org/10.1016/j.intcom.2010.04.001

Oliver, R. L. (1999). Value as excellence in the consumption experience, In Consumer value: a framework for analysis and research (1st ed.). M. Holbrook, London: Routledge.

Oliver, R. L. (1981). Measurement and evaluation of satisfaction process in retail setting. Journal of Retailing, 
$57,25-48$.

Panagiotakopoulos, C., \& Koustourakis, G. (2001). Dealing with 1st year University Students Computer Anxiety. Themes in Education, 2(1), 35-46.

Park, N., \& Yang, A. (2012). Online environmental community members' intention to participate in environmental activities: An application of the theory of planned behavior in the Chinese context. Computers in Human Behavior, 28, 1298-1306. http://dx.doi.org/ 10.1016/j.chb.2012.02.013

Reibstein, D. J. (2002). What attracts customers to online stores, and what keeps them coming back? Journal of the Academy of Marketing Science, 30(4), 465-473. http://dx.doi.org/ 10.1177/009207002236918

Reichheld, F. F., \& Schefter, P. (2000). E-loyalty: your secret weapon on the web. Harvard Business Review, $105-113$.

Richard, M. O. (2005). Modeling the impact of internet atmospherics on surfer behavior. Journal of Business Research, 58, 1632-1642. http://dx.doi.org/10.1016/j.jbusres.2004.07.009

Rose, S., Clark, M., Samouel, P., \& Hair, N. (2012). Online Customer Experience in e-Retailing: An empirical model of Antecedents and Outcomes. Journal of Retailing, 88(2), 308-322.

Pavlou, P., \& Fygenson, M. (2006). Understanding and prediction electronic commerce adoption: an extension of the theory of planned behavior. MIS Quarterly, 30(1), 115-143.

Sarkar, A. (2011). Impact of Utilitarian and Hedonic Shopping Values on Individual's Perceived Benefits and Risks in Online Shopping. International Management Review, 7(1), 58-95.

Schaupp, L. C., \& Bélanger, F. (2005). A conjoint analysis of online consumer satisfaction. Journal of Electronic Commerce Research, 6(2), 95-111.

Shankar, V., Smith, A., \& Rangaswamy, A. (2003). Customer satisfaction and loyalty in online and offline environments. International Journal of Research in Marketing, 20(2), 153-175.

Shu, W., \& Cheng, C. Y. (2012). How to improve consumer attitudes toward using credit cards online: An experimental study. Electronic Commerce Research and Applications, 11, 335-345. http://dx.doi.org/ 10.1016/j.elerap.2012.01.003

Szymanski, D. M., \& Hise, R. T. (2000). E-satisfaction: an initial examination. Journal of Retailing, 76(3), 309-322. http://dx.doi.org/10.1016/S0022-4359(00)00035-X.

Tarafdar, M., \& Zhang, J. (2008). Determinants of reach and loyalty-a study of website performance and implications for website design. The Journal of Computer Information Systems, 48(2), 16-24.

Trasorras, R., Weinstein, A., \& Abratt, R. (2009). Value, satisfaction, loyalty and retention in professional services. Marketing Intelligence and Planning, 27(5), 615-632.

Van der Heijden, H. (2004). User acceptance of hedonic information systems. MIS Quarterly, 28(4), 695-704.

Venkatesh, V., Thong, J. Y. L., \& Xu, X. (2012). Consumer acceptance and use of information technology: extending the unified theory of acceptance and use of technology. MIS Quarterly, 36(1), 157-178.

Wagner, J., \& Rydstrom, G. (2001). Satisfaction, trust and commitment: consumers relationships with online retailers. European Advances in Consumer Research, 5, 276-281.

Wang, Y. J., Hernandez, M. D., \& Minor, M. S. (2010). Web aesthetics effects on perceived online service quality and satisfaction in an e-tail environment: The moderating role of purchase task. Journal of Business Research, 63, 935-942. http://dx.doi.org/10.1016/j.jbusres.2009.01.016

Westbrook, R., \& Oliver, R. L. (1991). The dimensionality of consumption emotion patterns and consumer satisfaction. Journal of Consumer Research, 18, 84-91. http://dx.doi.org/10.1086/209243

Yang, Z., \& Peterson, R. T. (2004). Customer perceived value, satisfaction, and loyalty: The role of switching costs, Psychology and Marketing, 21(10), 799-822. http://dx.doi.org/10.1002/mar.20030

Yang, H. E., Wu, C. C., \& Wang, K. C. (2009). An empirical analysis of online game service satisfaction and loyalty. Expert Systems with Applications, 6, 1816-1825. http://dx.doi.org/j.eswa.2007.12.005

Yoo, W. S., Lee, Y., \& Park, J. K. (2010). The role of interactivity in e-tailing: Creating value and increasing satisfaction. Journal of Retailing and Consumer Services, 17(2), 89-96.

Zeithaml, V. A. (1988). Consumer perceptions of price, quality and value: a means-end model and synthesis of evidence. Journal of Marketing, 52, July, 2-22. http://dx.doi.org/10.2307/1251446 
Zhang, P. (2013). The affective response model: a theoretical framework of affective concepts and their relationships in the ICT context. MIS Quarterly, 37(1), 247-274.

\section{Notes}

Note 1. "The profile of remote and online buyers", Research realised for the FEVAD, October, 24th, 2012.

Note 2. "Pleasure" dimension was deleted because the items 10 and 11 have important correlations with two factors.

Note 3. "Organization" dimension was deleted because it doesn't have a good reliability (alpha=0.585) and "informational character" and "efficiency of the informational content" dimensions were merged to form only one factor.

Annex 1. Sample characteristics

\begin{tabular}{lll}
\hline Characteristics & & Percentage (\%) \\
\hline Age & Less than 25 years & $33,3 \%$ \\
& Between 25 and 35 years & $49,2 \%$ \\
& Between 36 and 45 years & $12,5 \%$ \\
More than 45 years & $5 \%$ \\
Gender & Women & $53,3 \%$ \\
Occupational & Men & $46,7 \%$ \\
status & Middle/senior executives & $19,2 \%$ \\
& Teachers & $15 \%$ \\
& Employees & $17,5 \%$ \\
& Students & $24,2 \%$ \\
& Functionary & $6,7 \%$ \\
& Liberal profession & $10 \%$ \\
& Unemployed & $7,5 \%$ \\
\hline
\end{tabular}

Annex 2. Scales

\begin{tabular}{|c|c|c|}
\hline Concept & Dimensions & Items \\
\hline Browsing & & 1. The percent of time I spent just looking around on the trip was fairly high \\
\hline \multirow[t]{2}{*}{ (Beatty and Ferrel, 1998) } & & 2. I would say that I was primary "just looking around" on this trip \\
\hline & & $\begin{array}{l}\text { 3. I devoted most of my attention to the items I planned to buy on this trip (Reversed } \\
\text { item) }\end{array}$ \\
\hline \multirow{10}{*}{$\begin{array}{l}\text { Perceived value } \\
\text { (Mathwick et al., 2001) }\end{array}$} & Visual appeal & 1. The way 3 suisses displays its products is attractive \\
\hline & & 2. 3suisses' $\mathrm{s}$ Internet site is aesthetically appealing \\
\hline & & 3. I like the way 3suisses's Internet site look \\
\hline & Entertainment & 4. I think 3suisses's Internet site is very entertaining \\
\hline & & 5. XYZ doesn't just sell products-it entertains me. \\
\hline & & 6. The enthusiasm of 3suisses's Internet site is catching, it picks me up \\
\hline & Escapism & 7. Shopping from 3suisses's Internet site "gets me away from it all". \\
\hline & & 8. Shopping from 3 suisses makes me feel like I am in another world \\
\hline & & 9. I get so involved when I shop from XYZ that I forget everything else \\
\hline & Intrinsic & $\begin{array}{l}\text { 10. I enjoy shopping from } 3 \text { suisses's Internet site for its own sake, not just for the items } \\
\text { I may have purchased. }\end{array}$ \\
\hline
\end{tabular}


enjoyment

Excellence

Efficiency

Economic value

Satisfaction

(Eroglu et al., (2003).)

Environmental cues

(Richard, 2005)

Loyalty

(Gremler, 1995)

Computer anxiety

Reduced version of Heinssen et al. (1987)'s scale

Structure

Entertainment

Informativeness

effectiveness
11. I shop from 3suisses's Internet site for the pure enjoyment of it.

12. When I think of 3suisses, I think of excellence

13. I think of 3suisses as an expert in the merchandise it offers

14. Shopping from 3 suisses is an efficient way to manage my time.

15. Shopping from 3suisses's Internet site makes my life easier.

16. Shopping from 3suisses's Internet site fits with my schedule.

17. 3 suisses products are a good economic value.

18. The prices of the product(s) I purchased from 3suisses's Internet site are too high, given the quality of the merchandise(Reversed item)

19. Overall, I am happy with 3suisses's prices.

1. Overall, navigational experience in 3suisses website was satisfying

2. Overall, this navigational experience in 3 suisses website was pleasant

3. Overall, I liked navigational experience in 3suisses website

Navigational cues

1. It is easy to use.

2. Navigational problems are limited.

3. There are good search agents to find information

4. Easy keywords to find information are used.

5. The structure is well-organized

6. It allows a great overview of its structure.

7. The structure is straightforward.

Organisation

8. Confusing site (Reversed item)

9. Irritating site (Reversed item)

10. Exciting site

11. Imaginative site

12. Entertaining site

13. Informative site

14. Useful site

15. Resourceful site

Information content 16. Information is accurate

17. Information is up-to-date

18. Product information is complete

1. I will recommend this site to a friend.

2. I have the intention to continue to visit this site.

3. If I have the possibility to buy goods via Internet, I have the intention to buy from this site in the future.

1. I hesitate to use a computer for fear of making mistakes that I can't correct

2.I feel insecure about my ability to interpret a computer printout

3. I have avoided computers because they are unfamiliar and somewhat intimidating to me

4. I have difficulty understanding the technical aspects of computers

5. The challenge of learning about computers is exciting 


\section{Copyrights}

Copyright for this article is retained by the author(s), with first publication rights granted to the journal.

This is an open-access article distributed under the terms and conditions of the Creative Commons Attribution license (http://creativecommons.org/licenses/by/3.0/). 